\title{
Serum zinc and hormonal profile in male dialysis patients receiving human recombinant erythropoietin
}

\author{
Zinco sérico e perfil hormonal de pacientes do sexo masculino submetidos à hemodiálise \\ em uso de eritropoetina humana recombinante
}

Maria Mouranilda Schleicher'; Flávio José Dutra de Moura'; Enzio Galvão Torreão Braz Diniz²; Carlos César Schleicher'; Tânia Torres Rosa ${ }^{3}$; José Garrofe Dorea ${ }^{4}$; Joel Paulo Russomano Veiga ${ }^{3}$

\begin{tabular}{|c|c|}
\hline unite & tra \\
\hline $\begin{array}{l}\text { Hemodialysis } \\
\text { Erythropoietin } \\
\text { Hematocrit } \\
\text { Albumin } \\
\text { Testosterone }\end{array}$ & $\begin{array}{l}\text { Introduction: Treatment with recombinant human erythropoietin (rHuEpo) is associated with an im- } \\
\text { provement in well-being and quality of life in patients submitted to maintenance hemodialysis (HD). } \\
\text { Objectives: The goal of this work was to evaluate the levels of sex hormones, hematocrit, albumin and } \\
\text { zinc in HD patients with rHuEpo therapy and compare them with those observed in patients without } \\
\text { rHuEpo treatment. Material and methods: Two groups of twelve male HD patients each were selected for } \\
\text { a transversal study; one did not receive rHuEpo (group 1) whereas the other one did (group } 2 \text { ). Levels of } \\
\text { hematocrit, albumin, zinc, luteinizing hormone (LH), follicle-stimulating hormone (FSH), prolactin, and } \\
\text { testosterone were determined. Results: Group } 2 \text { patients showed significantly higher medians (p }<0.05 \text { ) } \\
\text { of testosterone ( } 4.65 \text { vs. } 3.5 \mathrm{ng} / \mathrm{mL} \text { ), hematocrit ( } 30.5 \mathrm{vs.} 22 \%) \text {, albumin ( } 3,9 \mathrm{vs.} \mathrm{3,7g/dL)} \mathrm{and} \mathrm{zinc} \mathrm{(} 62.5 \\
\text { vs. } 50.5 \text { microg/dL) than group } 1 \text { patients. Discussion: In this study rHuEpo treatment resulted in higher } \\
\text { hematocrit, testosterone, zinc and albumin. It is suggested that, in patients recipients of rHuEpo, higher } \\
\text { levels of zinc and testosterone may be factors that contribute to relieve sexual dysfunction and improve } \\
\text { quality of life. Conclusions: In HD patients, hematocrit, albumin, serum zinc and testosterone levels were } \\
\text { higher in rHuEpo recipients when compared with patients not receiving this hormone therapy. }\end{array}$ \\
\hline
\end{tabular}

\section{resumo}

Introdução: Em pacientes submetidos à hemodiálise crônica (HD), o tratamento com eritropoetina humana recombinante ( $\mathrm{rHuEpo}$ ) está associado a melhora no bem-estar geral e na qualidade de vida. Objetivos: 0 objetivo do presente trabalho foi avaliar os níveis dos hormônios sexuais e do zinco em pacientes sob HD e em uso de rHuEpo em comparação com pacientes sem tratamento com essa droga. Material e métodos: Dois grupos de doze pacientes do sexo masculino cada um, submetidos à $H D$, sendo um deles sem uso de rHuEpo (grupo 1) e o outro utilizando a droga (grupo 2), foram selecionados para um estudo transversal, comparando-se os níveis séricos do zinco, da albumina, dos hormônios FSH, LH, prolactina, testosterona e do hematócrito. Resultados: No grupo 2, os valores de testosterona (4,65 vs. 3,5ng/ml), hematócrito $(30,5 \mathrm{vs}$. $22 \%)$, albumina (3,9 vs. 3,7g/dl) e zinco (62,5 vs. 50,5microg/dl) foram significativamente maiores do que no grupo $1(p<0,05)$. Discussão: Sugere-se que, em pacientes recipientes da rHuEpo, os níveis mais altos de hematócrito, zinco, albumina e testosterona possam ser fatores que contribuam para melhorar a disfunção sexual e a qualidade de vida dos pacientes hemodialisados. Conclusão: Os pacientes em HD em uso da rHuEpo apresentaram níveis mais elevados de testosterona, zinco e hematócrito quando comparados com os pacientes sem a terapia hormonal. key words

Hemodiálise

Eritropoetina

Hematócrito

Albumina

Testosterona

Zinco 


\section{Introduction}

Hemodialysis (HD) technique has gradually improved over the last few decades, providing a more effective and safer treatment and resulting in better quality of life for end-stage renal disease (ESRD) patients. Modern technology with volumetric control of ultra-filtration, improvement in biocompatible membranes and control of dialysis doses, as well as treatment of anemia with recombinant human erythropoietin (rHuEpo), have contributed to decrease co-morbidity in $\mathrm{HD}^{(13,19)}$. Despite improvements, hormonal dysfunction is common in uremic patients, and the associated impaired function of the hypothalamic-pituitary-gonadal axis is not reversed by dialysis therapy. Erectile dysfunction, decreased libido, low frequency of intercourse, oligo- or azoospermia, and gynecomastia are common problems among male uremic patients. These symptoms are very distressing and can seriously damage patient's self-esteem, causing anxiety and possibly affecting outcome. The origin of this disorder is multifactorial, yet its precise mechanism remains unclear. Its cause in ESRD patients undergoing chronic dialysis has been related to decreased testosterone, higher folliclestimulating hormone (FSH) and luteinizing hormone (LH) levels (hypergonadotropic hypogonadism), higher prolactin, impaired function of the hypothalamic-pituitarygonadal axis, zinc deficiency, anemia, and vascular and neurological complications ${ }^{(21)}$.

The use of rHuEpo therapy appears to relieve sexual dysfunction $^{(2)}$ and to increase serum testosterone levels in uremic patients ${ }^{(33)}$. These effects are probably the result of anemia correction, improvement in nutritional status and/or a direct metabolic action of $\mathrm{rHuEpo}^{(21)}$.

\section{Objectives}

The objective of this study was to evaluate hormonal profile, hematocrit, serum zinc, and albumin levels in HD patients as a function of rHuEpo therapy. Therefore, a transversal study was proposed, including two groups of HD patients; one group received rHuEpo therapy and the other one did not.

\section{Material and methods}

The ethics committee of the Universidade de Brasilia's Hospital approved the study, and patients gave written informed consent to participate.
This transversal study was conducted at the dialysis center of the university hospital and included 24 patients on $\mathrm{HD}$ (four hours, three times a week). Patients were divided into two groups. Group $1(n=12)$ consisted of patients that had not been in rHuEpo treatment for the last six months because during the study rHuEpo therapy was only available to patients enrolled in the transplant program. Patients in group $2(n=12)$ received rHuEpo regularly for six months, before the start of the study to obtain a target hematocrit of $32 \%-33 \%$. Twelve healthy male subjects were included as a reference group for hormones and hematological parameters.

Patients with a history of alcohol ingestion, smoking, and use of antihypertensives and/or other drugs that interfere with the sexual function were excluded. Patients with depression or undergoing treatment with antidepressive drugs were also excluded. None of the patients in either group received blood transfusions during the study or in the preceding two weeks. Heparin was used as anticoagulant during hemodialysis, and a cellulose acetate dialyzing membrane was employed. All patients were on a diet consisting of $1 \mathrm{~g} / \mathrm{kg} /$ day of protein of high biological value. Calcium carbonate was prescribed with the meals $(1.5-3 \mathrm{~g} /$ day) to keep serum phosphate levels below $5.5 \mathrm{mg} / \mathrm{dl}$ and serum calcium levels below $10.5 \mathrm{mg} / \mathrm{dl}$.

Blood samples were withdrawn from all subjects at 7:00 a.m. after overnight fasting and before the hemodialysis session. Disposable plastic syringes without rubber were used to avoid zinc contamination. Serum was separated from clotted blood by centrifugation with care to avoid hemolysis in zinc-free tubes. Serum was removed and stored at $-20^{\circ} \mathrm{C}$. Serum zinc concentration was determined by atomic absorption spectrophotometry (Perkin-Elmer, Norwalk, Conn, USA) ${ }^{(30)}$.

Serum concentrations of hormones (testosterone, FSH, $\mathrm{LH}$, and prolactin) were measured by double antibody radioimmunoassay (Kit Coat-A-Count, Diagnostic Products Corporation, Los Angeles, CA, USA). Albumin was determined using autoanalyser, and hematocrit, by the automatized method used at Brasília's University Hospital.

\section{Statistical analysis}

Because of the small number of subjects and non-normal distribution of other variables evaluated, the data were analyzed employing non-parametric statistics. Continuous variables in the three groups were simultaneously compared using Kruskal-Wallis test followed by Student-Newman- 
Keuls test for multiple comparisons between pairs of groups. Age and months on dialysis in patients submitted to hemodialysis were compared using Mann-Whitney rank sum test. The correlation between zinc and other laboratory variables was studied using Spearman rank correlation coefficient (rs). Statistical significance level of differences for all comparisons was set at $5 \%(\mathrm{p}<0.05)$. Data analysis was done with SigmaStat ${ }^{\circledR}$ (Jandel Scientific, USA, 1993) software package.

\section{Results}

For the subjects enrolled in this study, demographic characteristics, months on dialysis and etiology of end-stage renal failure are shown in Table 1. There were no significant differences for age and time on dialysis between the two groups studied.
A summary of results of laboratory variables is shown in Table 2. Patients of group 1 had lower median serum testosterone levels than rHuEpo-treated group $(p<0.05)$. However, median serum testosterone was significantly lower in patients of both groups than in healthy reference subjects ( $p<0.05$, Kruskall-Wallis). There was no statistically significant difference for serum prolactin between the two groups, but patients of both groups showed a significantly higher median serum prolactin than respective values for reference subjects $(p<0.05)$. Despite a higher median of serum FSH and LH levels in HD patients, there was no statistically significant difference when they were compared with reference subjects.

Serum albumin from groups 1 and 2 patients was significantly lower than the respective values of reference subjects and was significantly lower in patients from group 1 than that observed in group $2(p<0,05)$. Patients

Table 1

Demographics, months on dialysis, and causes of renal failure of the subjects studied

\begin{tabular}{lcccc}
\hline Variable & Reference subjects & Non-treated patients & Treated patients & $p^{* *}$ \\
\hline Age (years)* & $40(19-50)$ & $40(19-51)$ & $40.5(19-51)$ & 0.862 \\
Sex (male/female ratio) & $12 / 0$ & $12 / 0$ & $12 / 0$ & - \\
Race (white/black ratio) & $7 / 5$ & $7 / 5$ & $6 / 6$ & - \\
Months on dialysis* & - & $33(8-64)$ & $36(9-54)$ & 0.954 \\
Chronic glomerulonephritis & - & 5 & 4 & - \\
Hypertensive nephrosclerosis & - & 4 & 4 & - \\
Polycystic renal disease & - & - & 1 & - \\
Chronic interstitial nephritis & - & 1 & 1 & - \\
Indeterminate causes & - & 2 & 2 & - \\
\hline Vors & - & & & \\
\hline
\end{tabular}

*Values shown are median (range); ** p value for comparison between the treated and non-treated patient groups by means the Mann-Whitney rank sum test.

Table 2

\begin{tabular}{lcccc}
\hline Laboratory data & $\begin{array}{c}\text { Reference subjects } \\
(n=12)\end{array}$ & $\begin{array}{c}\text { Non-treated patients } \\
(n=12)\end{array}$ & $\begin{array}{c}\text { Treated patients } \\
(n=12)\end{array}$ & $p$ value* $^{*}$ \\
Zinc (microg/dL) & $86.5(65-95)$ & $50.5(42-67)^{+}$ & $62.5(52-82)^{\sharp+}$ & $<0.05$ \\
Testosterone $(\mathrm{ng} / \mathrm{mL})$ & $7.5(5-10)$ & $3.5(1.5-5.2)^{+}$ & $4.6(3.5-4.6)^{\sharp+}$ & $<0.05$ \\
Prolactin $(\mathrm{ng} / \mathrm{mL})$ & $9.5(7.5-15.5)$ & $19.2(10-46)^{+}$ & $23.1(10.5-47)^{+}$ & $<0.05$ \\
FSH (mUI/mL) & $8.7(6-16.8)$ & $10.2(2-56)$ & $14.5(4-36)$ & $>0.05$ \\
LH (mUI/mL) & $2.7(1.9-3.6)$ & $3.1(1.8-10.3)$ & $3.6(2.6-9.2)$ & $>0.05$ \\
Albumin $(\mathrm{g} / \mathrm{dL})$ & $4(3.7-4.3)$ & $3.7(2.7-4)^{+}$ & $3.9(3.3-4.3)$ & $<0.05$ \\
Hematocrit $(\%)$ & $43.5(40-47)$ & $22(16-25)^{+}$ & $30.5(27-33)^{\sharp+}$ & $<0.05$ \\
\hline
\end{tabular}

${ }^{*} p$ value for simultaneous comparison between the three groups by means of the Kruskal-Wallis test; " significant difference $(p<0.05)$ between treated and non-treated patient groups; ' significant difference $(p<0.05)$ between treated or non-treated patient groups and the control group. 
receiving rHuEpo (group 2) had significantly higher serum zinc concentrations than group 1 . However, serum zinc of reference subjects was significantly higher than that in both hemodialysis groups $(p<0.05)$. As expected, hematocrit levels were lower in non-treated patients as compared to rHuEpo recipients. Nevertheless, both hemodialysis groups had lower hematocrit than reference subjects $(p<0.05)$.

In HD subjects, we observed a positive correlation between zinc and albumin ( $r s=0.502, p=0.012)$ and between zinc and hematocrit ( $r s=0.553, p=0.005$ ). There were no significant correlations between zinc and testosterone $(r s=0.395, p=0.055)$ and zinc and prolactin $(r s=-0.286, p=0.173)$.

\section{Discussion}

This transversal study was possible because there was a group of male HD patients who, voluntarily, did not enroll in the transplant program of the University Hospital and, during a period of six months, did not have access to rHuEpo because at the time of the study the drug was temporarily restricted to patients listed for transplant. Another group of male HD patients in use of rHuEpo and comparable in terms of age, causes of end stage renal disease, and dialysis length was enrolled.

\section{Hormonal profile}

Our results showed that rHuEpo-treated patients exhibited higher hematocrit, testosterone, and zinc levels. Indeed, patients treated with rHuEpo showed enhanced levels of testosterone and non-significant differences in $\mathrm{LH}$ and FSH levels in relation to untreated subjects.

The administration of rHuEpo to patients with chronic renal failure seems to alter pituitary gonadal feedback mechanism with reduced plasma concentration of $\mathrm{LH}$ and $\mathrm{FSH}$, and to increase plasma testosterone levels ${ }^{(15,26)}$. However, this effect of rHuEpo on patients undergoing hemodialysis was not uniformly present ${ }^{(3,16 \text {, }}$ 32). Plasma concentration of $\mathrm{LH}$ was elevated in patients on maintenance hemodialysis, and the increase is thought to result from diminished release of testosterone from Leydig cells and decreased LH renal clearance ${ }^{(18)}$. FSH levels also increased, but less consistently. The moderate response of $\mathrm{LH}$ to low levels of testosterone suggests a dysfunction in the pituitary gonadal axis as demonstrated in hemodialized subjects ${ }^{(17,27,29)}$. Although our patients showed higher $\mathrm{LH}$ and FSH values, there was no significant difference in relation to reference subjects, which may be due to the great variability and small number of subjects. Indeed, the lack of significant differences in LH and FSH between treated and non treated patients suggests that rHuEpo may have a direct effect or may act as a paracrine factor stimulating steroidogenesis in Leydig cells ${ }^{(6,34)}$.

Improvement of sexual function after rHuEpo treatment was attributed to normalization of elevated prolactin concentrations $^{(28)}$, but has not yet been confirmed ${ }^{(2,15)}$. Patients in dialysis complaining of sexual dysfunction after correction of anemia with rHuEpo were characterized by higher levels of serum testosterone, but not by suppression of hyperprolactinemia or hyperestrogenism ${ }^{(16)}$. We observed that the median serum prolactin was high in both HD groups with lack of a significant difference between them.

\section{Zinc}

In rHuEpo-treated patients, we observed significantly higher levels of zinc than in non-treated patients, which is in agreement with other works ${ }^{(10,11)}$ It has been observed that in rHuEpo recipients zinc erythrocytes levels and serum albumin were significantly higher than in patients without rHuEpo therapy ${ }^{(23)}$, suggesting that rHuEpo use in HD may significantly improve protein nutritional status, as well as the disturbance in zinc metabolism. These effects of rHuEpo in serum zinc have not always been reported ${ }^{(14)}$. Zinc deficiency has also been related to gonadal failure in chronic renal diseases ${ }^{(20)}$ and in HD patients. This can be due to reduced dietary intake, zinc malabsorption, and/or possible leaching of zinc through the dialysis membrane ${ }^{(9,}$ 22). Indeed, the administration of supplemental zinc to HD patients resulted in increase in plasma testosterone and sperm count and decline in $\mathrm{LH}$ and $\mathrm{FSH}$ levels ${ }^{(20)}$, effects that were not observed by other authors ${ }^{(1,31,35)}$. Furthermore, zinc deficiency in rats and in humans may be associated with disturbance in testicular function and Leydig cell failure ${ }^{(8,}$ 12), even though experimental work showed that zinc concentrations in testis were significantly higher in uremic compared to non-uremic sham-operated rats ${ }^{(25)}$. However, a strong negative correlation between leukocyte-zinc and serum prolactin suggested that depletion of total zinc stores could be an important mechanism of hyperprolactinemia in uremic patients(5), although we did not observe a significant correlation between serum prolactin and serum zinc. This is in agreement with previous reports in dialysis subjects ${ }^{(4,24)}$.

The importance of zinc deficiency in uremia and its role on physiopathology of hormonal dysfunction remains poorly understood. Moreover, only a small part of the total 
body zinc content is in the blood, and serum zinc may not reflect the exact amount of zinc stores in uremic patients submitted to chronic dialysis. A difference in concentrations of this trace element between plasma, erythrocytes, and whole blood was observed ${ }^{(36)}$. Despite that, serum zinc may be considered a marker of nutritional status in dialysis patients and it was positively correlated with pre-albumin, a useful marker of nutritional status ${ }^{(7)}$. Higher levels of zinc in patients treated with rHuEpo were possibly related to wellbeing and appetite improvements, and a better nutritional status that resulted from anemia correction.
In conclusion, patients treated with rHuEpo showed, in association with improvement of anemia, higher levels of serum zinc, albumin and testosterone.

\section{Acknowledgments}

The authors wish to express their gratitude to Dr. Luiz Fernando Junqueira Jr., of Cardiovascular Research Laboratory, UnB, for his support and help with statistical analysis, and to Fernando Vicente de Padua and Carolina Veiga Cunha for their technical assistance.

\section{Referências}

I. BERMÚDEZ, |.A. et al. Endocrine profile in patients with chronic renal failure under zinc replacement. Arch Androl, v. 9, n. 2, p. 167-9, 1982.

2. BOMMER, J. et al. Improved sexual function during recombinant human erythropoietin therapy. Nephrol Dial Transplant, v. 5, n. 3, p. 204-7, 1990.

3. CARLSON, H. E. et al. Endocrine effects of erythropoietin. Int J Artif Organs, v. 18, n. 6, p. 309-14, 1995.

4. CASTRO, A. V. et al. Prolactin and zinc in dialysis patients. Biol Trace Elem Res, v. 88, n. I, p. 1-7, 2002.

5. CATICHA, O. et al. Total body zinc depletion and its relationship to the development of hyperprolactinemia in chronic renal insufficiency.J Endocrinol Invest, v. 19, n. 7, p. 44I-8, 1996.

6. FORESTA, $C$. et al. Erythropoietin stimulates testosterone production in man. J Clin Endocrinol Metab, v. 78, n. 3, p. 753-6, 1994

7. GRZEGORZEWSKA, A. E.; MARIAK, I. Zinc as a marker of nutrition in continuous ambulatory peritoneal dialysis patients. Advances Per Dial, v. I 7, n. I, p. 223-9, 200 I.

8. HANDI, S. A.; NASSIF, O. I.; ARDAWI, M. S. Effect of marginal or severe dietary zinc deficiency on testicular development and functions of the rat. Arch Androl, v. 38, n. 3, p. 243-53, 1997.

9. HOSOKAWA, S.; OYAMAGUCHI, A.; YOSHIDA, O. Trace elements and complications in patients undergoing chronic hemodialysis. Nephron, v. 55, n. 4, p. 375-9, 1990.

10. HOSOKAWA, S.; YOSHIDA, O. Effect of erythropoietin (rHuEpo) on trace elements and quality of life $(\mathrm{Qol})$ in chronic hemodialysis patients. Int J Clin Pharmacol Ther, v. 32, n. 8, p. 4I5-2I, 1994.

I I. HOSOKAWA, S.;YOSHIDA, O. Effects of erythropoietin on trace elements in patients with chronic renal failure undergoing hemodialysis. Nephron, v. 65, n. 3, p. 4I4-7, 1993.

12. HUNT, C. D. et al. Effects of dietary zinc depletion on seminal volume and zinc loss, serum testosterone concentrations, and sperm morphology in young men. American J Clin Nutr, v. 56, n. I, p. 148-57, 1992

13. KALANTAR-ZADEH, K. et al. Association among SF36 quality of life measures and nutrition, hospitalization, and mortality in hemodialysis. J Am Soc Nephrol, v. 12, n. 12, p. 2797-806, 2001.

14. KAMINSKA-GALWAS, B. et al. Level of zinc, copper, selenium and nickel in serum of patients treated for chronic renal failure with hemodialysis - influence of erythropoietin therapy. Pol Arch Med Wewn, v. 89, n. 5, p. 368-76, 1993.

15. KOKOT, F. et al. Function of endocrine organs in hemodialized patients of long-term erythropoietin therapy. Artif Org, v. 19 , n. 5, p. 428-35, 1995.

16. LAWRENCE, I G. et al. Erythropoietin and sexual dysfunction. Nephrol Dial Transplant, v. 12, n. 4, p. 74I-7, 1997.

17. LeROITH, D. et al. Dissociation of pituitary glycoprotein response to releasing hormones in chronic renal failure. Acta Endocrinol (Copenh), v. 93, n. 3, p. 277-82, 1980.

I 8. LIM,V. S.; FANG,V. S. Restoration of plasma testosterone levels in uremic men with clomiphene citrate. J Clin Endocrinol Metab, v. 43, n. 6, p. 1370-7, 1976.

19. LOWRIE, E. G. Chronic dialysis treatment: clinical outcome and related process of care. Am J Kidney Diseases, v. 24, n. 2, p. 255-66, 1994

20. MAHAJAN, S. K. et al. Effect of oral zinc therapy on gonadal function in hemodialysis patients. A double blind study. Ann Intern Med, v. 97, n. 3, p. 357-61, 1982.

21.PALMER, B. F. Disease of the month. Sexual dysfunction in uremia. JAm Soc Nephrol, v. 10, n. 6, p. 1381-8, 1999.

22. PENG, S. J. et al. Trace metals and dialysis equipments in hemodialysis patients: a multicenter collaboratory study. Nephrology, v. 3, suppl. I, p. S3I6-S2I, 1997.

23. PIETRZAK, I.; BLADEK, K.; BULIKOWSKI, W. Comparison of magnesium and zinc levels in blood in end stage renal disease patients treated by hemodialysis or peritoneal dialysis. Magnes Res, v. I5, n. 3-4, p. 229-36, 2002.

24. PONTICELLI, C.; MOCCHEGIANI, E.; FABRIS, N. Effect of oral zinc administration on prolactin and thymulin circulating levels in patients with chronic renal failure.J Clin Endocrinol Metab, v. 68, n. I, p. 186-90, 1989.

25. RIBEIRO, R. C. et al. Absence of zinc testicular deficiency in the 
sexual dysfunction of experimentally induced uremic rats. Nephron, v. 30, n. 4, p. 36I-3, 1982.

26. SCHAEFER, F. et al. Changes in the kinetics and biopotency of luteinizing hormone in hemodialized men during treatment with recombinant human erythropoietin. J Am Soc Nephrol, v. 5, n. 5, p. 1208-15, 1994.

27. SCHAEFER, F. et al. Immunoreactive and bioactive luteinizing hormone in pubertal patients with chronic renal failure. Cooperative Study Group on Pubertal Development in Chronic Renal Failure. Kidney Int, v. 45, n. 5, p. 1465-76, 1994.

28. SCHAEFER, R. M. et al. Improved sexual function in hemodialysis patients on recombinant erythropoietin: a possible role for prolactin. Clin Nephrol, v. 3I, n. I, p. I-5, 1989.

29. SCHALCH, D. S. et al. Plasma gonadotropins after administration of $\mathrm{LH}$ releasing hormone to patients with renal or hepatic failure.J Clin Endocrinol Metab, v. 4I, n. 5, p. 921-5, 1975.

30. SMITH Jr., J. C.; BUTRIMOVITZ, G. P. Direct measurement of zinc in plasma by atomic absorption spectroscopy. Clin Chem, v.
28, n. 8, p. |487-9|, 1979.

31. SPRENGER, K. B. et al. Zinc and sexual dysfunction. Contrib Nephrol, v. 38, n. 2, p. I19-25, 1984.

32. STEFFENSEN, G.;AUNSHOLT, NA. Does erythropoietin cause hormonal changes in hemodialysis patients? Nephrol Dial Transplant, v. 8, n. II, p. 1215-8, 1993

33. WU, S. C.; LIN, S. L.; JENG, F. R. Influence of erythropoietin treatment on gonadotropic hormone levels and sexual function in male uremic patients. Scand J Urol Nephrol, v. 35, n. 2, p. 136-40, 200।.

34. YAMAMOTO, Y.; SOFIKITIS, N.; MIYAGAWA, I. Effects of erythropoietin, bromocryptine and hydralazine on testicular function in rats with chronic renal failure. Andrologia, v. 29, n. 3, p. |4|-4, 1997.

35.ZETIN, M.; STONE, R. A. Effects of zinc in chronic hemodialysis. Clin Nephrol, v. I3, n. I, p. 20-5, 1980.

36. ZIMA, T. et al. Trace elements in hemodialysis and continuous ambulatory peritoneal dialysis patients. Blood Purif, v. 16, $\mathrm{n}$. 5, p. 253-60, 1998. 